\title{
Clinical profile of patients treated with cefepime/tazobactam: A new B-lactam/ß-lactamase inhibitor combination
}

\author{
Abdul Ghafur, Ashwini Tayade, Priyadarshini Kannaian \\ Department of Infectious Diseases, Apollo speciality Hospital, Chennai, South India
}

\begin{abstract}
Objectives: Cefepime/tazobactam is a new B-lactam/ß-lactamase inhibitor combination licensed for clinical use by Drugs Controller General of India. Aim of our study was to analyze the clinical efficacy and safety of cefepime/tazobactam in patients with sepsis. To the best of our knowledge, this is the first published clinical study on this drug.
\end{abstract}

Materials and methods: A retrospective observational study on the efficacy and safety of cefepime/tazobactam was conducted at a tertiary care hospital, South India. Patients who had a clear source of infection, having a single organism as the causative agent and being treated with cefepime/tazobactam alone were analyzed for efficacy and those cases who had a clear source of infection but either had multiple organism grown or cultures being negative or those patients who received a combination of antibiotics were analyzed for the safety analysis.

Results: Thirty two patients satisfied our study criteria. All 15 patients in the efficacy group (nine with ventilator associated pneumonia, three tracheitis, two bacteraemia and one with urosepsis) had complete clinical cure, with microbiological cure in cases where a repeat culture was indicated. There were no significant side effects in any of the evaluable 32 patients assessed for safety.

Conclusion: Cefepime/tazobactam is a safe and effective agent to treat patients with nonlife threatening sepsis due to Gram negative bacteria. J Microbiol Infect Dis 2012; 2(3): 79-86

Key words: Cefepime/tazobactam, BL-BLI, carbapenem sparing strategy.

\section{Cefepim/tazobaktam ile tedavi edilen hastaların klinik seyri: Yenir bir ß-laktam/ß- laktamaz inhibitor kombinasyonu}

\section{ÖZET}

Amaç: Sefepim/tazobaktam, Hindistan Genel İlaç Kontrol Dairesi tarafından klinik kullanım lisansı verilen yeni bir ßlaktam/ß-laktamaz inhibitor kombinasyonudur. Bu çalışmanın amacı sefepim/tazobaktam'ın sepsis hastalarında etkinliğini ve güvenirliliğini incelemek idi. Bizim bilgimize göre bu makale bu ilaçla ilgili basılan ilk klinik çalışmadır.

Gereç ve yöntem: Sefepim/tazobaktam'ın etkinlik ve güvenilirliği üzerine Güney Hindistan'da üçüncü basamak bir bakım merkezinde retrospektif bir gözlem çalışması yapıldı. Enfeksiyon kaynağı belli olan, tek bir mikroorganizmanın etken olarak izole edildiği ve tek başına sefepim/tazobaktam ile tedavi edilen hastalar etkinlik açısından incelendi ve belirgin bir enfeksiyon kaynağı olduğu halde birden çok organizma üreyen veya kültürü negatif olan yada tedavi için bir antibiyotik kombinasyonu alan hastalar güvenilirlilik analizi için incelendi.

Bulgular: Hastalardan 32'si bizim kriterlerimizi tam olarak karşılamaktaydı. Etkinlik grubundaki 15 hasta (dokuz ventilatör ilişkili pnömoni, üç trakeit, iki bakteriyemi ve bir ürosepsis) klinik iyileşme gösterdi, hastaların mikrobiyolojik iyileşmesi tekrarlanan kültürlerle gösterildi. Güvenilirlilik grubunda değerlendirilen 32 hastanın hiçbirinde ciddi bir yan etki görülmedi.

Sonuç: Sefepim/tazobaktam, gram negatif bakterilern etken olduğu hayatı tehdit etmeyen sepsisin tedavisinde güvenli ve etkin bir ilaçtır.

Anahtar Kelimeler: Sefepim/tazobaktam, BL-BLI, karbapenem koruma stratejisi 


\section{INTRODUCTION}

Increasing prevalence of carbapenem resistant Gram negative bacteria is a serious global challenge, restricting therapeutic options against these bacteria to a limited number of drugs, especially colistin. Reports of colistin resistant bacteria have been on the rise in recent years, opening window to the pan resistance and a world without antibiotics. ${ }^{1-3}$ To circumvent this scenario, a strategy of carbapenem restriction and exploring alternative treatment strategies with ß-lactam/ßlactamase agents has been advocated by various experts. . $^{4-6}$

Many Indian centers have reported very high prevalence of ESBL producers. ${ }^{7}$ Irrational usage of carbapenem in centres without functioning antibiotic policy and extensive usage even in places with good antibiotic stewardship, to treat infections due ESBL producing gram negative organisms, has contributed to the resistance saga. ${ }^{8}$ Unlike hospitals in many western countries, for instance, United States where Gram positive resistance is the predominant menace, Indian hospitals are haunted by multi drug resistant Gram negative bacteria. Most of the Indian hospitals do not have a functioning antibiotic policy, in tune with the absence of a national antibiotic policy, fostering indiscriminate usage of antibiotics and skyrocketing antimicrobial resistance. ${ }^{9}$ ß-lactam/ß-lactamase inhibitor combinations like piperacillin-tazobactam and cefoperazonesulbactam have already proven to be good alternatives to treat patients with less severe sepsis, thus restricting usage of carbapenem only to severe life-threatening sepsis. ${ }^{10-12} \mathrm{~A}$ recent metaanalysis concluded that piperacillin tazobactam can be a suitable alternative to carbapenems for treating patients with bloodstream infections due to ESBL-E. coli if active in vitro, to be used as definitive therapy. ${ }^{4}$

Increase in carbapenem usage has a direct relationship to increase in carbapenem resistant Gram negative bacteria. ${ }^{13}$ Carbapenem sparing and restriction strategy could result in a reduction in carbapenem usage and carbapenem resistance rate. ${ }^{14}$ Combination of a fourth generation cephalosporin with a ß-lactamase inhibitor has the theoretical advantage of additional activity against AmpC and possibly OXA enzymes over a third generation cephalosporin. ${ }^{5}$ Pharmacokinetic profiles of these two molecules are complemen- tary to each other to be used as a combination. Cefepime has a half-life of 2 hrs., plasma protein binding of $20 \%$ and $85 \%$ urinary excretion in the unchanged form while tazobactam has corresponding figures of $1 \mathrm{hr}$., $20-23 \%$, and $80 \%$. $^{15-17}$ Two grams of cefepime and 250 mg of tazobactam, can be the optional dose in this combination. ${ }^{18}$ Cefepime/tazobactam is a new promising combination already licensed by the Drug Controller General of India (DCGI) and increasingly used in Indian hospitals. No published clinical data is available on this drug and limited numbers of in vitro studies are published till now. Recent studies have recorded good in vitro activity of cefepime/ tazobactam. As per the published data on invitro susceptibility of Gram negative bacteria, from our own centre; $60.5 \%$ were sensitive to piperacillin/tazobactam, $46.2 \%$ to cefepime, $80.4 \%$ to cefepime/tazobactam, $71.3 \%$ to cefoperazone/ sulbactam, $79.1 \%$ to imipenem and $78.2 \%$ to meropenem. Addition of tazobactam increased the susceptibility of cefepime from $46.2 \%$ to $80.4 \%$ in gram negative isolates in general; from 34.4 to $87.9 \%$ in E. coli, from 42.3 to $81.0 \%$ to Klebsiella, from 72.0 to $81.4 \%$ in Pseudomonas and 17.2$54.5 \%$ to Acinetobacter. ${ }^{19}$ In a multi-centre invitro study, cefepime tazobactam had a better susceptibility profile $(80 \%)$ than piperacillin/tazobactam $(66.7 \%)$ and cefoperazone/sulbactam $(68.6 \%)$ to Enterobacteriaceae. ${ }^{20}$ Other invitro studies have been recently published with similar results. ${ }^{21,22}$ Aim of our study was to analyse the clinical efficacy and safety of cefepime/tazobactam in patients with sepsis.

\section{MATERIALS AND METHODS}

A retrospective observational study on the clinical efficacy of the new ß-lactam/ß-lactamase inhibitor antibiotic combination: cefepime/tazobactam was conducted at a 300 bedded tertiary care Oncology, Neurosurgical and Orthopaedic Centre in South India. Both adult and paediatric patients with a clear source of infection and received cefepime/tazobactam for more than 48 hours were included in the study. Cases where the source of infection was unclear or cefepime/tazobactam was administered for less than 48 hours or cefepime/tazobactam was started and immediately changed over to another antibiotic or patients where cefepime/tazobactam was changed to another antibiotic due to resistant isolates and in 
those the response to the treatment could not be assessed were excluded from the study.

The main study group included cases that fulfilled the criteria of having a clear source of infection, having a single organism as the causative agent and being treated with cefepime/ tazobactam alone. Those cases that had a clear source of infection but either had multiple organism grown or cultures being negative or those patients who received a combination of antibiotics were analyzed separately and included for the safety analysis.

Case records were analyzed for parameters like age, sex, critical care stay, apache II score ${ }^{23}$, duration of fever, invasive procedures if any, mechanical ventilation, presence of central line, dialysis, total leukocyte count, neutrophil count, liver function tests, renal function test, coagulation profile, blood, urine, nasopharyngeal secretion and other cultures and sensitivity, radiological imaging, reason for the change of antibiotics, prior hospitalization and prior use of antibiotics in past 9 months, cytotoxic or corticosteroid usage, dose, duration and route of administration of cefepime/tazobactam, other antibiotic combinations used and their duration, final microbiological and clinical outcome.

\section{RESULTS}

Thirty two patients satisfied the inclusion and exclusion criteria (Figure 1). Out of the total 32 patients, cultures were positive intwenty three. Fifteen of these cases received monotherapy with cefepime/tazobactam and remaining 8 either had polymicrobial growth or received combination treatment. Fifteen patients having culture positivity with one organism and treated with cefepime/ tazobactam monotherapy were included in the first group and hence were taken up to study the efficacy; while all 32 were included in the safety evaluation. Seven among the total twenty three positive isolates were resistant to Carbapenem and sensitive to cefepime/tazobactam (Table 1).

Of the 15 patients in the first group (Table I), five were admitted with trauma, four with Cerebrovascular accident, three with malignancy, two with Space occupying lesion in the brain and one with subglottic stenosis. Six patients $(40 \%)$ developed ventilator associated pneumonia, 3 (20\%) hospital acquired pneumonia, $3(20 \%)$ had tracheitis, $2(13.33 \%)$ had bacteremia and one had urosepsis. Mean age of these patients was 52.5, mean Apache II score was 14.46, and average critical care stay was 10.1 days. Five of 15 patients grew Pseudomonas, three Klebsiella, three were E. coli, three Acinetobacter and one Pantoea. Ten isolates were resistant to cefepime, 5 sensitive to cefepime and all were sensitive to cefepime/tazobactam.

Cefepime- tazobactam dosage administered was $2.25 \mathrm{~g}$ 8th hourly for 12 adults, 12 th hourly for 2 adults and $1.125 \mathrm{~g}^{\text {th }}$ hourly for one pediatric patient. Average duration of treatment was 9.4 days. Average cumulative dose of cefepime/ tazobactam received by adults was $60.1 \mathrm{~g}$ and the pediatric patient $27 \mathrm{~g}$. Microbiological clearance was seen in all 4 patients where a repeat culture was performed. All 15 patients improved clinically and were discharged. Two patients with bacteremia (one E. coli and the other Pantoea, both isolates cefepime resistant and cefepime tazobactam sensitive) had microbiological and clinical cure. The paediatric patient with $E$. coli UTI had clinical cure. A repeat urine culture was not done to assess microbiologic cure.

Eight patients either had polymicrobial growth or received combination treatment (Figure 2). Mean age of these eight patients was 56.6 years; average intensive care stay was 12.5 days and mean Apache II score was 16 . Four $(50 \%)$ had bacteremia, $2(25 \%)$ Ventilator associated pneumonia, one $(12.5 \%)$ had intra-abdominal infection and one $(12.5 \%)$ had soft tissue infection. Elizabethkingia meningoseptica was the growth in all bacteremic patients. Two of these patients were treated with combination of cefepime/tazobactam, teicoplanin and rifampicin; one patient with cefepime/tazobactam, tigecycline and teicoplanin combination and one received cefepime/tazobactam with rifampicin. Among the 2 VAP patients, one grew Acinetobacter and was treated with intravenous cefepime/tazobactam and nebulised colistin and the other patient had Pseudomonas (pan sensitive) and E. coli (cefepime resistant) and responded well to cefepime/tazobactam monotherapy. E. coli and Gemella morbillorum was identified from intra-abdominal abscess of one patient and was treated with cefepime/tazobactam and teicoplanin combination. Pus sample from the soft tissue infection of the face of one patient had polymicrobial growth with Klebsiella 
(cefepime resistant), Pseudomonas (pan sensitive) and Methicillin Resistant Staphylococcus aureus and received a combination of cefepime/ tazobactam, aztreonam and linezolid.

Out of the nine culture negative cases (Figure 3), 5 had hospital acquired pneumonia and four had meningitis. Mean age was 35.3 year; Average intensive unit stay was 7.44 days and average Apache II score was 11.2. Four of the five hospital acquired pneumonia patients received cefepime/tazobactam alone and remaining 1 received combination with teicoplanin. One patient with meningitis received cefepime/tazobactam monotherapy while two received combination with vancomycin and one received vancomycin and colistin initially and then switched over to cefepime/tazobactam with vancomycin. All these patients responded well clinically to the treatment.

None among the 32 patients had any serious side effect. The liver function test, renal function test and coagulation profile prior to therapy and after treatment showed no untoward changes caused by the drug. All the patients had a good clinical response and were stable and discharged.

Draw backs of the study were; the retrospective design, case selection not being consecutive and the exclusion of those patients where cefepime/tazobactam was changed to another antibiotic due to a resistant isolates.

Table 1. Clinical profile of patients in the study group.

\begin{tabular}{|c|c|c|c|c|c|c|c|c|c|c|}
\hline Case & Diagnosis & $\begin{array}{l}\text { Site of } \\
\text { Isolation }\end{array}$ & Organism & $\begin{array}{l}\text { Cefepime } \\
\text { S/R }\end{array}$ & $\begin{array}{l}C T \\
S / R\end{array}$ & $\begin{array}{c}\text { Carbapenem } \\
\text { S/R }\end{array}$ & $\begin{array}{l}\text { CT } \\
\text { dose }\end{array}$ & $\begin{array}{c}\text { Duration } \\
\text { in days }\end{array}$ & $\begin{array}{l}\text { Micro } \\
\text { clearance }\end{array}$ & $\begin{array}{c}\text { Clinical } \\
\text { improvement }\end{array}$ \\
\hline 1 & Bacteraemia & Blood & E. coli & $\mathrm{R}$ & $S$ & $S$ & $2.25 \mathrm{~g} \mathrm{BD}$ & 18 & Cleared & Yes \\
\hline 2 & Bacteraemia & Blood & Pantoea & $\mathrm{R}$ & $S$ & $S$ & $2.25 \mathrm{~g}$ TDS & 8 & Cleared & Yes \\
\hline 3 & VAP & TT & $\begin{array}{l}\text { Klebsiella } \\
\text { pneumonia }\end{array}$ & $\mathrm{R}$ & $S$ & $S$ & $2.25 \mathrm{~g}$ TDS & 10 & NR & Yes \\
\hline 4 & VAP & TT & $\begin{array}{l}\text { Acinetobacter } \\
\text { baumannii }\end{array}$ & $\mathrm{R}$ & $S$ & $\mathrm{R}$ & $2.25 \mathrm{~g}$ TDS & 10 & NR & Yes \\
\hline 5 & VAP & TT & $\begin{array}{l}\text { Pseudomonas } \\
\text { aeruginosa }\end{array}$ & S & $S$ & $S$ & $2.25 \mathrm{~g}$ TDS & 7 & NR & Yes \\
\hline 6 & VAP & $\mathrm{NE}$ & $\begin{array}{l}\text { Pseudomonas } \\
\text { aeruginosa }\end{array}$ & $S$ & $S$ & $S$ & $2.25 \mathrm{~g}$ TDS & 10 & NR & Yes \\
\hline 7 & VAP & ET BAL & $\begin{array}{l}\text { Pseudomonas } \\
\text { aeruginosa }\end{array}$ & S & $S$ & $S$ & $2.25 \mathrm{~g}$ TDS & 9 & Cleared & Yes \\
\hline 8 & VAP & TT & $\begin{array}{l}\text { Acinetobacter } \\
\text { baumannii }\end{array}$ & $\mathrm{R}$ & $S$ & $S$ & $2.25 \mathrm{~g}$ TDS & 10 & Cleared & Yes \\
\hline 9 & $\begin{array}{l}\text { Tracheitis/ } \\
\text { ?VAP }\end{array}$ & TT & $\begin{array}{l}\text { Pseudomonas } \\
\text { aeruginosa }\end{array}$ & S & $S$ & $S$ & $2.25 \mathrm{~g}$ TDS & 8 & NR & Yes \\
\hline 10 & $\begin{array}{l}\text { Tracheitis/ } \\
\text { ?VAP }\end{array}$ & TT & $\begin{array}{l}\text { Acinetobacter } \\
\text { baumannii }\end{array}$ & $\mathrm{R}$ & $S$ & $\mathrm{R}$ & $2.25 \mathrm{~g}$ TDS & 10 & NR & Yes \\
\hline 11 & $\begin{array}{l}\text { Tracheitis/ } \\
\text { ?HAP }\end{array}$ & $\mathrm{NE}$ & $\begin{array}{l}\text { Klebsiella } \\
\text { pneumonia }\end{array}$ & $\mathrm{R}$ & $S$ & $S$ & $2.25 \mathrm{~g}$ TDS & 10 & NR & Yes \\
\hline 12 & HAP & TT & $\begin{array}{l}\text { Klebsiella } \\
\text { pneumonia }\end{array}$ & $\mathrm{R}$ & $S$ & $S$ & $2.25 \mathrm{~g}$ TDS & 18 & NR & Yes \\
\hline 13 & HAP & $\begin{array}{l}\text { ET } \\
\text { aspirate }\end{array}$ & E. coli & $\mathrm{R}$ & $S$ & $S$ & $2.25 \mathrm{~g} \mathrm{BD}$ & 10 & NR & Yes \\
\hline 14 & HAP & Sputum & $\begin{array}{l}\text { Pseudomonas } \\
\text { aeruginosa }\end{array}$ & $S$ & $S$ & $S$ & $2.25 \mathrm{~g}$ TDS & 6 & NR & Yes \\
\hline 15 & Urosepsis & Urine & E. coli & $\mathrm{R}$ & $\mathrm{S}$ & $\mathrm{R}$ & $1.125 \mathrm{~g}$ TDS & 8 & NR & Yes \\
\hline
\end{tabular}

CT: Cefepime/tazobactam, TT: Tracheostomy tube, ET: Endotradheal, NA: Nasopharyngeal aspirate, VAP: Ventilator Associated Pneumonia, HAP:Hospital Acquired Pneumonia, R: Resistant, S: Sensitive, NR: Not-repeated, 


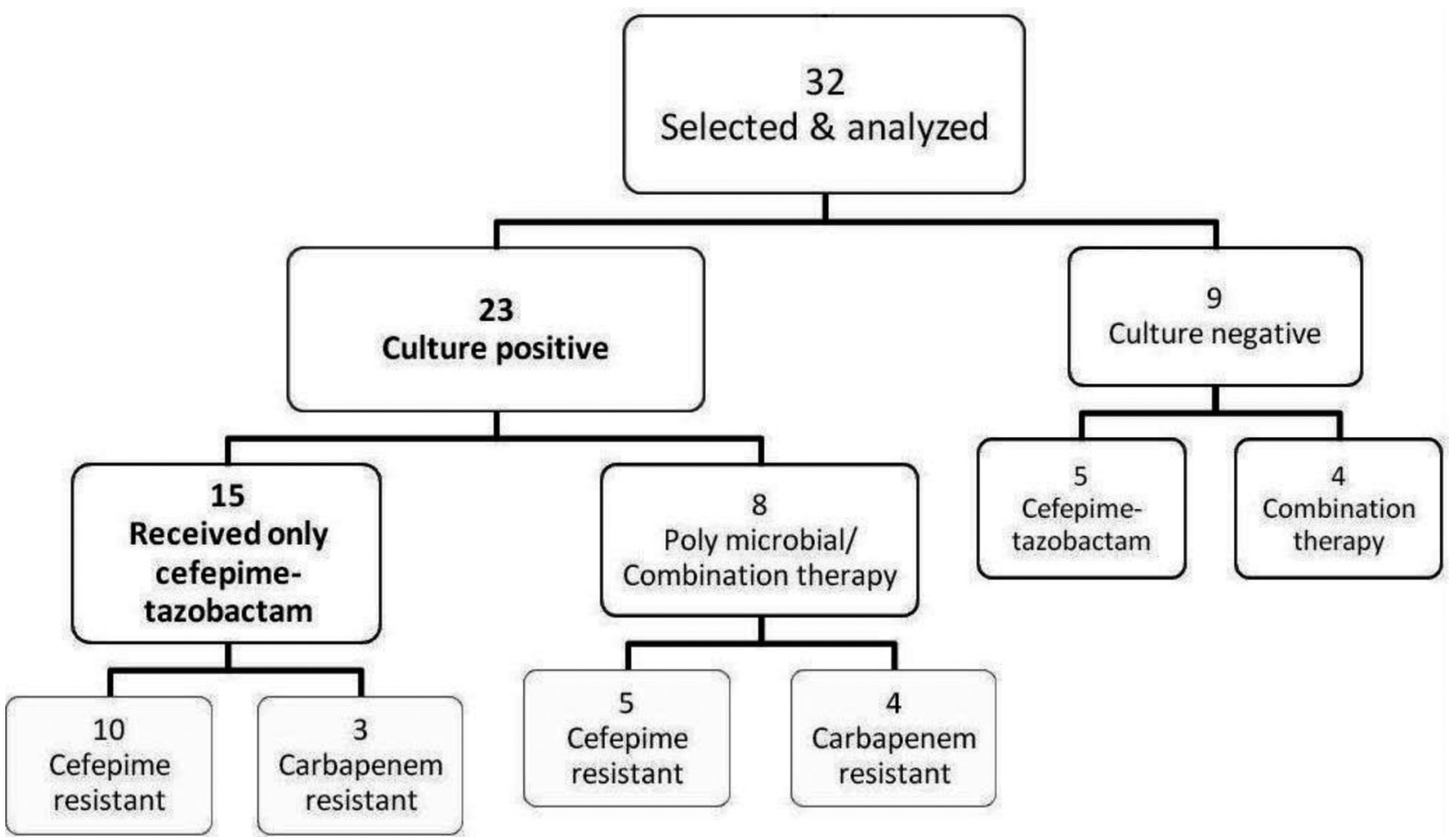

Figure 1. Overview of study design

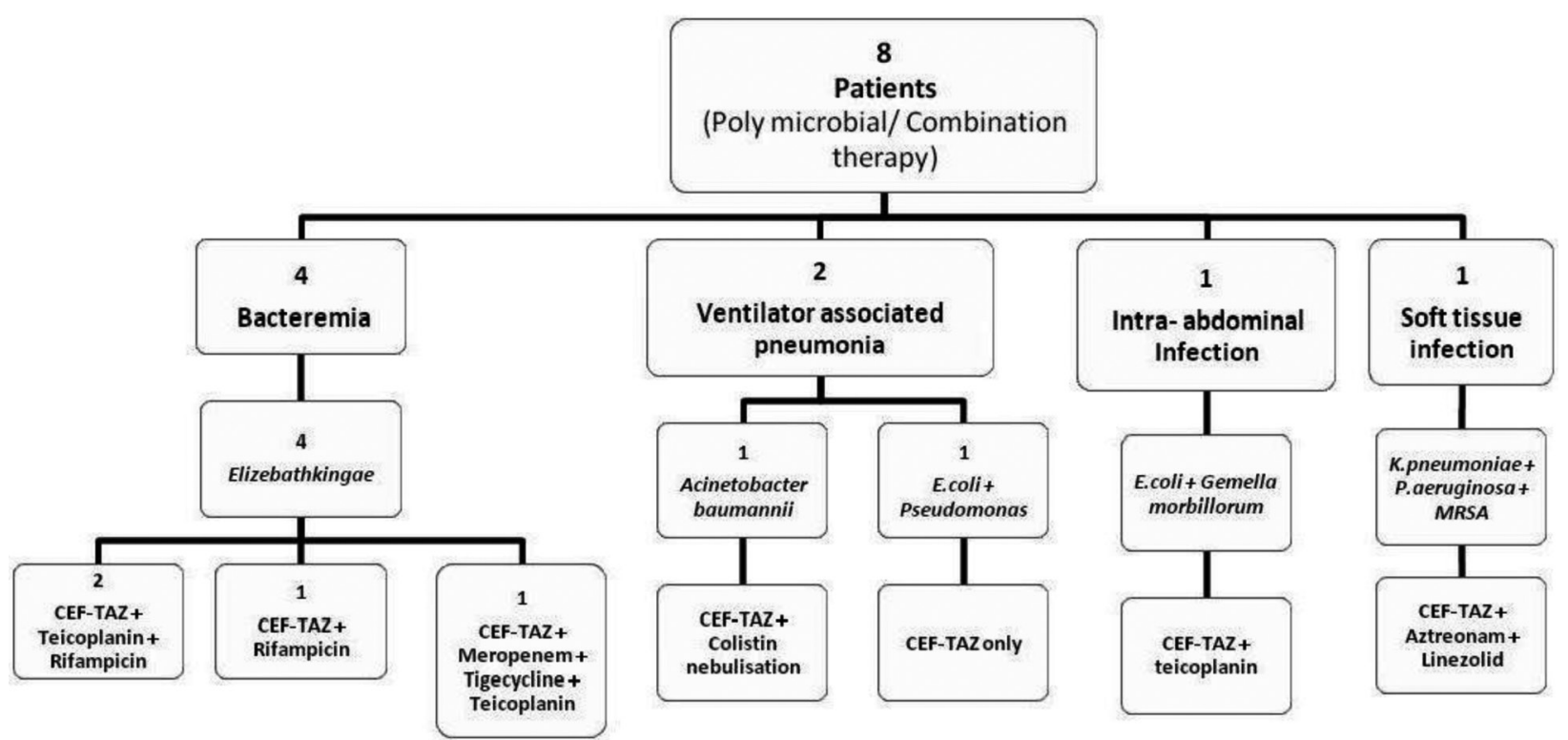

Figure 2. Overview of cases with polymicrobial growth/combination therapy. 




Figure 3. Overview of culture negative cases

\section{DISCUSSION}

Increasing carbapenem resistance scenario has prompted many experts to explore and recommend usage of non carbapenem group of drugs and combinations. ${ }^{4.5}$ Carbapenem resistance being a major threat, experts in Indian subcontinent also have advocated the use of BL-BLI combinations in moderately severe infections due to ESBL producers. ${ }^{6,19}$ Multiple recent publications revealed good invitro activity of this drug against various Gram negatives. Cefepime/tazobactam was found to have very good invitro susceptibility profile to Gram negatives, as per the published data from our own centre.

To the best of our knowledge, this is the first clinical study on cefepime/tazobactam. Our hospital, being a tertiary care oncology and neurosurgical center, with high Gram negative bacterial resistance rates ;patients admitted to critical care units with sepsis especially when the source is initially unclear or already having positive cultures for multidrug resistant or extremely drug resistant Gram negative bacteria; receive combination of antibiotics. Such patients could not be taken for analysis of efficacy \& safety of cefepime/tazobactam.

Cefepime/tazobactam was found to be a safe agent, with no serious side effects in any of our evaluable patients. All the 15 patients in the group selected for analyzing efficacy; where the source of infection was clear, with a single organism isolated and cefepime/tazobactam was used as monotherapy, had good clinical response to the drug. Microbiological clearance was not significant in most patients in this group as they were having ventilator associated pneumonia or had tracheostomy tube, where repeat culture positivity could only have indicated colonization. Both patients with bacteraemia (one E. coli and the other Pantoea, both cefepime resistant and cefepime tazobactam sensitive) had microbiological and clinical cure. The paediatric patient with E. coli UTI had clinical cure. In the second group where the patient had polymicobial growth or a combination of antibiotics was used, half of the patients (4 out of 8 ) had Elizabeth kingia meningoseptica bacteraemia. Combination treatment being the norm in managing these cases, analyzing efficacy of cefepime/tazobactam was difficult. In culture negative group, 4 patients with HAP and the one with neurosurgical meningitis received cefepime/tazobactam as monotherapy and all of these cases responded well clinically.

Engineering new ß-lactam antibiotics stable against ESBL producers is a time consuming and expensive strategy. A practical solution to the problem will be studying new combinations of ß-lactam antibiotics with ß-lactamase inhibitor molecules. Amoxycillin-clavulanate and piperacillin-tazobactam are widely used in India and abroad with plenty of available clinical data and 
established breakpoints for the laboratory detection of susceptibility. Cefoperazone-sulbactam is extensively used in most of Indian hospitals and in many other countries. Unfortunately this combination lacks large scale randomized control trials, not having FDA licensing, with no established laboratory breakpoints by any of the reputed guideline committees. These draw backs did not hinder extensive use of this molecule, serving as a carbapenem sparing strategy, in non-life threatening infections. Various guidelines like IDSA and ATS have recommended cefepime as a therapeutic option for treating patients with Hospital acquired pneumonia, severe community acquired pneumonia, complicated urinary tract infection, complicated skin and soft tissue infections and meningitis. ${ }^{24,25}$

Very high ESBL prevalence in India makes cefepime a less attractive option against these indications. Combination of cefepime with a ß-lactamase inhibitor molecule significantly enhanced the susceptibility profile of this molecule and the current study suggests good clinical outcome .With the antibiotic pipeline almost dry against the gram negatives, it is wise to use BL/BLI combinations in patients with less severe sepsis.

\section{CONCLUSION}

Various invitro studies have already underscored the good in-vitro activity of cefepime/tazobactam combination against Gram negative bacteria. To the best of our knowledge, this is the first published clinical study on this drug. Cefepime/ tazobactam is a safe and effective agent to treat patients with nonlife threatening sepsis due to Gram negative bacteria. A serious drawback of the study is its retrospective observational design, with possible selection bias. A randomized, controlled multicentre clinical trial of this drug with other BL-BLI agents like cefoperazone/sulbactam or piperacillin/tazobactam is a necessity of the time, in order to spare precious carbapenem group of antibiotics and to dampen the impact of the scary scenario of increasing extremely drug resistant and pan drug resistant Gram negative bacteria.

\section{REFERENCES}

1. Falagas ME, Bliziotis IA, Kasiakou SK, Samonis G, Athanassopoulou $P$, Michalopoulos A. Outcome of infections due to pandrug- resistant (PDR) Gram-negative bacteria. BMC Infect Dis 2005 ; 5: 24-28.

2. Marchaim D, Chopra T, Jason M Pogue, et al. Outbreak of Colistin-Resistant, Carbapenem-Resistant Klebsiella pneumonia in Metropolitan Detroit, Michigan. Antimicrob Agent Chemother 2011; 55: 2593-2599.

3. Taneja N, Singh G, Singh M, Sharma M. Emergence of tigecycline \& colistin resistant Acinetobacter baumanii in patients with complicated urinary tract infections in north India. Indian J Med Res 2011; 133: 681-684.

4. Rodríguez-Baño J, Navarro MD, Retamar $P$, et al. $\beta$-Lactam/ $\beta$ Lactam inhibitor combinations for the treatment of bacteremia due to extended-spectrum $\beta$-lactamase-producing Esch 7 erichia coli: A post hoc analysis of prospective cohorts. Clin Infect Dis 2012: 54:167-174.

5. Livermore DM, Hope R, Mushtaq S, Warner M. Orthodox and unorthodox clavulanate combinations against extended spectrum ß-lactamase producers. Clin Microbiol Infect 2008; 14:189-193.

6. Deshpande P, Rodrigues C, Shetty A, Kapadia F, Hegde A, Soman R. New Delhi Metallo-ß-lactamase (NDM-1) in Enterobacteriaceae: Treatment options with Carbapenems Compromised. J Assoc Physicians India 2010; 58:147-149.

7. Chaudhuri BN, Rodrigues C, Balaji V, et al. Incidence of ESBL Producers amongst Gram-negative Bacilli Isolated from Intra-abdominal Infections across India (Based on SMART Study, 2007 Data). J Assoc Physicians India 2011; 59:1-6.

8. Abdul Ghafur K. An obituary- On the Death of antibiotics! J Assoc Physicians India 2010; 58:143-144.

9. Abdul Ghafur K. Can India be the Wing Commander in the Global fight against Antimicrobial Resistance? J Assoc Physicians India 2012; 60:42-43.

10. Jauregui LE, Appelbaum PC, Fabian TC, Hageage G, Strausbaugh L, Martin LF. A randomized clinical study of cefoperazone and sulbactam versus gentamicin and clindamycin in the treatment of intra-abdominal infections. J Antimicrob Chemother 1990; 25:423-433.

11. Karaman S, Vural S, Yildirmak Y, Emecen M, Erdem E, Kebudi R. Comparison of piperacillin tazobactam and cefoperazone sulbactam monotherapy in treatment of febrile neutropenia. Pediatr Blood Cancer 2012; 58:579-583

12. Bodey G, Abi-Said D, Rolston K, Raad I, Whimbey E. Imipenem or cefoperazone-sulbactam combined with vancomycin for therapy of presumed or proven infection in neutropenic cancer patients. Eur J Clin Microbiol Infect Dis 1996; 15:625634.

13. Goel N, Wattal C, Oberoi JK, Raveendran R, Datta S, Prasad KJ. Trend analysis of antimicrobial consumption and development of resistance in non-fermenters in a tertiary care hospital in Delhi, India. JAC 2011; 66:1625-30

14. Ghafur A, Nagvekar V, Thilakavathy S, Chandra K, Gopalakrishnan R, Vidyalakshmi P. "Save antibiotics, save lives": an Indian success story of infection control through persuasive diplomacy. Antimicrob Resist Infect Control 2012, 1:2934.

15. Maxipime $®$ (Cefepime). U.S. Food and Drug Administration. [Online]. 2009 (Cited 2012 July 25). Available from: URL:http://www.accessdata.fda.gov/drugsatfda_docs/ label/2009/050679s032lbl.pdf

16. Perry CM, Markham A. Piperacillin/Tazobactam an updated review of its use in the treatment of bacterial infections. Drugs 1999; 57: 805-843.

17. Zosyn® (Cefepime). U.S. Food and Drug Administration. [Online]. 2012 (Cited 2012 July 25). Available from: URL: 
http://www.accessdata.fda.gov/drugsatfda_docs/label/2012/ 050684s055s061_050750s016s020lbl.pdf.

18. Mouton JW, Melchers R, Mil AV. In Vitro Activity of Cefepime alone and in combination with Tazobactam against ESBL producers. Poster session presented at ICAAC 2010, 12- 15 Sept; Boston, USA; A- 2251.

19. Ghafur A, Pushparaju R, Nalini S, Rajkumar K, Sureshkumar $D$. Sensitivity pattern of Gram negative bacteria to the new ß-lactam/ß-lactamase inhibitor combination: Cefepime/tazobactam. J Microbiol Infect Dis 2012;2(1):120-125.

20. Manoharan A, Madhan S, Kronvall G, Mathai D. Establishing interpretative breakpoints for cefepime/tazobactam: a novel B-lactam/ B-lactam inhibitor combination. 22 ${ }^{\text {nd }}$ European Congress of Clinical Microbiology and Infectious Diseases 2012;. 31 $1^{\text {st }}$ March-3 ${ }^{\text {rd }}$ April. London, UK. Abstract no: 947.
21. Sharma A, Gupta A, Arora A. Cefepime/tazobactam: A new BL/BLI combination against ESBL producing Gram negative Bacilli. Int J Pharm Biomed Sci 2012; 3(2): 35-38.

22. Panchatcharam SN, Ramasubramanian V, Gopalakrishnan R, Ghafur A, Thirunarayan M. Cefepime/tazobactam: a promising therapeutic option. Abstract No: $50.011,15^{\text {th }}$ ICID, Bangkok, Thailand, June 13-16, 2012.

23. Knaus WA, Draper EA, Wagner DP, Zimmerman JE. "APACHE II: a severity of disease classification system". Critical Care Medicine 1985; 13 (10): 818-829.

24. Tunkel AR, Hartman BJ, Kaplan SL, et al. Practice Guidelines for Bacterial Meningitis .Clin Infect Dis 2004; 39:1267-1284.

25. IDSA/ATS Guidelines for CAP in Adults. Clin Inf Dis 2007:44 (Suppl 2); S29-71. 